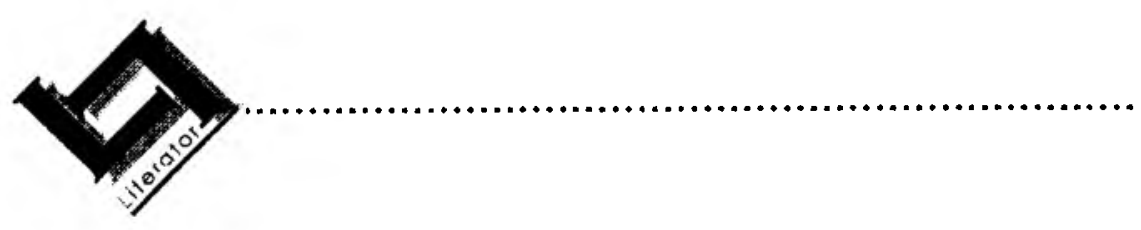

\title{
Writing of(f) the women of the National Women's Monument
}

\author{
Elsie Cloete \\ Department of English \\ Vista University (East Rand Campus) \\ BENONI \\ E-mail: clte-el@erne.vista.ac.za
}

\begin{abstract}
Writing off(f) the women of the National Women's Monument

The rise of nationalisms throughout the twentieth century presents a constellation of discourses in which the notion of "woman" has undergone phases of mobilisation and dismissal depending on the stage of national consciousness reached. The brochures of the National Women's Monument, written to augment the reasons for the monument's erection, reveal the problematics of Afrikaner nationalism and gender. In this paper, tentative parallels are drawn between Afrikaner nationalism and the new emergent African nationalism in South Africa in which the issues of women and nationalism are considered to be products of the same discourse despite increasing rights accruing to women generally.
\end{abstract}

\section{Introduction}

A few kilometres outside Bloemfontein a traveller will find the National Women's Monument. The monument was unveiled in 1913 to commemorate those Boer women and children who died in British concentration camps during the Anglo-Boer War. For eighty years it remained the only national monument in the world dedicated solely to women and children. In 1993 the Vietnam Women's Memorial, which adjoins the Memorial Wall, was unveiled in Washington DC. There are a great many monuments and memorials around the world which have women as primary focus, but for 80 years none except the monument outside Bloemfontein had national status.

Considering the innumerable web-sites, the many conferences, articles, tours available to famous battle sites and re-evaluations of the Anglo-Boer War that 
are currently taking place in anticipation of the centenary commemorations, it is perhaps also appropriate to consider the discursive terrain that the National Women's Monument (NWM) has occupied for close on a century.

Revisiting the NWM is warranted for two other reasons. Firstly, this century has seen the unprecedented emergence of nationalisms across the world and calls evoking the nation state appear set to prevail well within the next century too. A dominant Afrikaner nationalism has waned, but a new multi-cultural nationalism is on the upswing in South Africa. Nationalisms are not static phenomena: with respect to women, I contend that Afrikaner nationalism progressed through principally stages of mobilisation and dismissal before it became a nationalism subaltern to the new African nationalism. As far as women are concerned, the first stage of nationalism calls for women to become mothers of the nation. In 1989 Gaitskell and Unterhalter (1989) examined the question of mothers of the nation by making a comparative analysis of nation, race and motherhood in Afrikaner nationalism and the African National Congress (ANC). They felt that the mothers of the nation affected by these different nationalisms were fundamentally different on the grounds of widely divergent positions in current South African society on the basis of racial, cultural, economic, ethnic and political variables. Looking at it from a discursive point of view, however, there are significant parallels and many rhetorical convergences as far as mobilising women for a cause are concerned. Despite new affirmative policies with regard to women, I believe that the discourses current in both the exclusive Afrikaner nationalism and the more inclusive African nationalism of South Africa will continue to affect women. It is my contention that both the Afrikaner and the African nationalist movements are part of the same discursive framework in the Foucauldian sense and that the production of motherhood, for nationalistic purposes, amongst others, owes its genesis to the same constellation of discourses. The nationalist imperative requires women and women's groups to subsume issues of gender equality and to "affiliate" to the nationalist rhetoric.

South Africa's new constitution entrenches non-sexism. There is, however, a vast difference between such endorsement in a document, and such practice in a country where only a small percentage of women and men have the social and material resources to enforce such practice. Laying open the discourses which emerged around the NWM might provide pointers to the vicissitudes of the future position of women.

The second reason why the unteasing of discourses around the NWM might provide insight for the future relates to the question of unsettlement and settlement. In periods of war, or siege, civil disturbance or struggle or even in periods of migration such as the Great Trek and the rural-urban migration of women in the twentieth century, women are allowed far greater latitude in their actions than in periods of settlement and quiet. If there is a cause for liberation, 
women are hailed as those that yoked themselves to ploughs for lack of oxen, as those who planted bombs, took up arms, and as those who did things normally only associated with men. Once homes are being built or rebuilt, once the fear of capture or death has loosened its grip, once a government is in place and in power, old practices reassert themselves, the former rhetoric of the mother's rightful place manifests itself again, and from the war-time freedoms accorded women, the old, sedimented layers of notions about "a woman's place" again emerge. It would appear that changes in society's attitudes towards women during a period of trauma or stress (i.e. the Great Trek and the Anglo-Boer War or the struggle for liberation by South Africa's disenfranchised) are only temporary. As soon as life returns to "normal" the women's sphere becomes redefined and maintained by the prevailing patriarchal structures, regardless of the events of the preceding century or the immediate past. The rhetoric that has sedimented over the NWM is one place where one can begin to identify and sort out the discourses of war, conflict and peace, power and nationalism.

\section{Background to the Monument}

One of the reasons for incarcerating the women in the concentration camps during the Anglo-Boer War was to prevent "the guerrillas being helped by civilians [women]" (Pakenham, 1982:494). Kitchener's first priority was to win the war and in this he was successful. Pakenham notes that "[M]eat was at first not included in the rations given to the women and children, whose menfolk were still out on commando, which provided a useful economy and a useful encouragement for the men to come in and surrender" (Pakenham, 1982:494). The prevalence of typhoid, extremely poor medical facilities, lack of water and milk and the fact that one in five of those incarcerated died in the camps, left, as Pakenham notes, "a gigantic scar across the minds of the Afrikaners: a symbol [the concentration camps] of deliberate genocide" (1982:495).

In exile in Europe, President Kruger is reported to have said that "our opponents expect our women, because of their intense suffering, to persuade the men to surrender, but even here they [the enemy] will be disappointed" (in Van Rensburg, 1966:46). Van Rensburg also reports General Smuts as writing that "barely a single letter that was smuggled out of the camps to the commando's neglected to encourage the men to fight to the death and never to bring the shame of surrender over their families" (1966:46).

During the war casualty rates were high on both sides: 7792 British soldiers were killed in battle, while 13250 died from disease. The battle/disease distinction has not been made as far as the Boer men are concerned: 6189 Boer men died on the battlefield, or from illness or as prisoners of war, or from accidents on commando during the same period. However, more than 26370 Boer women and children died of disease or hunger in the hastily constructed British concentration camps. The number of civilian deaths in a war that lacked 
the technologies of modern-day devastation is disproportionately high. These statistics are based on English Blue Books but it has been acknowledged that the figures are often contradictory and that mortality returns were only started some time after the camps had been in existence (in Van der Merwe, 1926:9). There is the likelihood that a great many more women and children died in the 43 camps set up across the country.

Records of black people who died in separate camps were not kept by the British, but the estimate of above 20000 is considered possible, while Colonel Jacobs, Director of the War Museum, thinks that 40000 dead is probably a more accurate figure (telephonic interview on 13 October 1997). Official British figures of black people who died in concentration camps pronounce that only 14154 died. Pakenham notes that "No one bothered to keep full records of the deaths" among the 107000 "black Boers" who had been placed in African concentration camps (1982:573). Both the Boers and the British considered the period of conflict "a white man's war", even though black men served as auxiliaries on both sides. After Lord Kitchener decreed that enemy farms had to be burnt down and the land rendered barren, coloured women were often incarcerated in the camps along with their employers (see Van Heyningen, 1991).

The National Women's Monument was erected in memory of only white Boer women and children. Considering the discourses current at the time, a time concurrent with the height of colonial incursion by the European powers, the indigenes hardly counted and were certainly not reckoned part of the nation. The Boers did not consider themselves removed from the colonial discourses of Europe either, so it is not surprising that when plans were mooted for a commemorative object honouring the women and children who died in the concentration camps, it was intended for whites only. Eighty years later the word "national" in this respect occupies contestable terrain in South Africa, but for the moment the debate regarding monuments and their status has not yet really entered the public domain as far as the NWM is concerned.

When the idea of erecting a monument was first mooted in 1906 by the ex-Free State president, M.T. Steyn, a committee of eminent men took on the responsibility of seeing the plans for the monument come to fruition. These "eminent men" included the President, professors, ministers of the church, generals, advocates and academics. In 1914, responsibility for and control of the monument was vested in the National Women's Monument Commission. The Commission exists to this day and its statute states "die kommissie is belas met die behoorlike bewaring en versorging van en die beheer oor die Nasionale Vrouemonument te Bloemfontein en die terrein waarop dit staan, en sal alles verrig in belang van die veilige behoud van hierdie volksmonument vir die nageslag van die Boere-nasie" (Van Schoor, 1993:13) [Briefly translated: "the 
Commission will do everything.to promote the preservation of this (national) monument']. The original statute along with the first decade's archival records disappeared from a Commission member's storeroom and the present statute, which Van Schoor (1993:13) believes was based on the "same principles as the original", was adopted in 1940. In terms of profession, more dominees (reverends) have served on the Commission than any other profession.

\title{
3. Remembering the Monument
}

The actual structure of the National Women's Monument stands as a sentinel apart, silhouetted against a small koppie. Its bronze inscription, positioned below the central obelisk, is in Dutch:

\author{
AAN ONZE \\ HELDINNEN \\ EN LIEVE KINDEREN \\ "UW WIL GESCHIEDE" \\ DIT NATIONAAL MONUMENT \\ IS OPGERICHT \\ TER NAGEDACHTENIS AAN DE \\ 26370 VROUWEN EN KINDEREN \\ DIE IN DE CONCENTRATIEKAMPEN \\ ZYN OMGEKOMEN, \\ EN AAN DE ANDERE \\ VROUWEN EN KINDEREN \\ DIE ELDERS TENGEVOLGE \\ VAN DEN OORLOG 1899-1902 \\ ZYN BEZWEKEN \\ ONTHULD 16 DECEMBER 1913
}

[To our heroines and dear children/ "Thy will be done"/ This national monument/ was erected in commemoration of the/ 26370 women and children/ who died/ in the concentration camps,/ and those other/ women and children/ who died elsewhere/ as a result of the war 1899-1902./ Unveiled 16 December 1913.]

On either side of the obelisk two bronze friezes depict the Boer women and children and their few belongings on the way to the camps and a company of women and children solemnly watching the death of a child in a camp tent. The former frieze bears the inscription "Voor Vryheid, Volk en Vaderland" [For Liberty, Volk and Fatherland], while the latter reads " $I k$ Zal $u$ Niet Begeven Ik Zal U Niet Verlaten" [I shall not forsake you I shall not leave you].

However, as time passes commemorative structures and their brief inscriptions do not always embody a clear and coherent account of the past and memories 
are often only half evoked. For many South Africans and foreign visitors (especially those from non-British former colonies) the impetus which gave rise to the NWM in the first place is virtually meaningless or only evokes a vague, indistinct recollection. It is at these intersections of memory, re-memory and even non-memory, that a monument's information brochure is intended to act as a supplementary mechanism of testimony to evoke the rememberance of the event or the people. The intention of a brochure, albeit that the memory being revoked is always already derivative, is to super-repossess before memory breaks down completely. It becomes in effect a depository of memory, which traces and shapes the event. But brochure writers have their own agendas.

A case in point are the three official National Women's Monument brochures published in 1926 (N.J. Van der Merwe), 1961 (J.J. Oberholster) and 1993 (M.C.E. van Schoor). Oberholster and Van Schoor were members of the Commission. Van der Merwe, although not a serving member, was nevertheless closely connected to the Commission and is best remembered as President Steyn's son-in-law and later biographer. These brochures were written ostensibly to elucidate events in the British concentration camps and to augment memory. But the way the women are regarded, gazed at and treated as objects of analysis by the three writers discursively represents the vicissitudes of attitudes toward Afrikaner women in the twentieth century. The three brochures "inscribe" the Afrikaner woman in different ways: as the "ideal" woman/mother, as woman denied and, as woman "lost". The reasons why the Monument was erected in the first place appear to have become of secondary importance.

The differences in approach, content and style are significant and do not simply reflect changing tastes in the way one presents information. Examining the ways the Afrikaner women are inscribed (or not inscribed) in the three brochures reveals a changing paradigm with regard to their place in society within the particularist nationalist context. Throughout there is the discursive seepage of Afrikaner nationalism.

\section{Mothers breast-feed the volk}

The first stage of nationalism as far as women are concerned, deals with women as mothers of the nation - expected to breast-feed the volk. The first brochure written by N.J. van der Merwe (1926) is a fine example of this view. This is a text intended to marshall the volk: where role models would be based on the male and female Boer heroes of the past. But this is not so. The men, such as President Steyn, Reverend Kestell and General De Wet, are lionised. The women, despite evidence of their indomitability, determinism and strength, have been transformed into docile prey.

In Van der Merwe's brochure one no longer finds the anomalous and often contradictory descriptions of the Boer women that one encounters in texts such 
as Postma's Die Boervrouw: moeder van haar volk (1918), or Stockenström's highly romanticised history of women in the Dutch-Afrikaner nation (1921). Postma, for instance, often contradicts his own opinions. At one stage he maintains that " $[\mathrm{N}]$ either with the vote, nor in public rowdiness, nor in boastfulness or flag waving does the Boer woman seek her power, but in the realisation and acceptance of her calling as mother who trusts quietly in God" (1918:163), while on the following page he hails and lauds the 1915 march by over 3000 women to the Union Buildings to hand a petition to the Governor General requesting amnesty for those men incarcerated after an armed rebellion (1918:164). The march and demonstration was accompanied by flag-waving delegates from all four colonies in the Union as is demonstrated in a poem by Hilda Postma (in Postma, 1918:168-170).

Van der Merwe, however, renders the Boer woman's character as relatively unproblematically defined and very patriotic. Despite evidence that the Afrikaner women often assumed what were commonly thought of as manly qualities, readers of Van der Merwe's 1926 text are presented with role models of women who are "patient" (p. 6, 13), "suffering" (p. 5, 6, 8, 13, 14), "afflicted", "frail" (p. 6, 13), "defenceless" (p. 6), "tender" (p. 6), "delicate" and "refined" (p. 6). Women are imagined as that weak section of society who have given their lives on the altar of freedom for love of the fatherland. Van der Merwe regularly quotes M.T. Steyn in his 1926 text: "Hulle lye is met moed en geduld gedra" (p. 5); “... dit was veel skoner vir die swakke vrou om onder al daardie siele en liggaamlike lye haar las te dra" (p. 6); "... watter eerbied dwing die tere vrou nie af nie ..." (p. 6) and so on. [Britz's translation of this text reads: "They suffered courageously and patiently ... it was a far nobler act of a frail woman to carry her burden under all the spiritual and physical suffering she had to endure ... how much more respect does not the frail woman command ..." (Britz, s.a.:6).]

Few would contest that there were genuine heroines amongst the concentration camp dead, but in the commemorative brochure they assume heroic status because of their suffering and affliction. They died for the fatherland and in fact, the words "vaderland" and "vaderlandsliefde" [fatherland and love of fatherland] occur on almost every page of the 57-page brochure.

In the 1926 text there is then the paradoxical expectation, which counters the camp dead's "frailty", that female descendants of the Boers who fought or died in the war are the only ones strong enough to nurture the fledgling volk into a healthy organism. Already in 1918 Postma had used the idea of nurture figuratively (nurturing the volk) and literally - noting that the Boer woman is remarkably fertile and that birth control is only practised by "demoralised Afrikaners" (1918:157). 
Brink (1990:273) maintains that the notion of the "volksmoeder" remained "constant during a time of great industrial, political and social change in southern Africa" (approximately between 1900-1950). While the notion remained constant, the Afrikaner women developed into a muted group, muted by the internalisation of the language consistently used to describe them and by the fact that such a redefinition entailed a space of muffled and suppressed subservience to the men and the volk. And indeed, the women collaborated in their confinement. The constraints associated with being a mother of the nation were seen as choice. The assignment of womanly responsibility and subservience as duty in the volks-context should be seen as far broader than assignment by the patriarchy. As far as the volk was concerned women assigned the role of "volksmoeder" to themselves as well. For example, a special committee of the Suid-Afrikaanse Vroue-federasie (SAVF) of the Transvaal had noted in its constitution that members had to "werk om onze voormannen te ondersteunen" [work to support our [male] leaders], while the Cape-based Afrikaanse Christelijke Vroue-vereniging (ACVV) stated in its constitution: "Wij verbinden ons, in de zaak van opvoeding, onze volksvoormannen die van onze zienswijze zijn, te steunen op elke mogelijke wijze" (in Stockenström, 1944: s.p.) [in matters of education, we are bound to support in every way possible, those men who are leaders and of the same opinions as us]. The perception of duty as choice belies the fact that this is a gendered subservience. And yet, the women's behaviour, their gestures and their opinions are manipulated and disciplined in time and in space, inscribed in the first instance by a volk and secondly in terms of gender.

Van der Merwe's brochure on the NWM is clearly intended as a mobilising text and the sentimental, emotionally charged language (which in retrospect borders on the banal) was not intended to add to the already impressive image of the Boer women's heroic actions of the past but was especially intended, it can be argued, to herd her legendary independence of spirit into the new laager of Afrikaner nationalism and racial purity. Totius, one of the most fervent of Afrikaner nationalist poets of that time, wrote a poem on the erection of the monument which also acts as the preface to Van der Merwe's text (1926:1). The first two lines of the poem, entitled "Oprigting van die Monument" are revealing:

Nou sien ek rys uit jongs verlee

'n Rachelbeeld, suiwerlik blank.

[From mists of recent past there rises

A Rachel vision shining white.

Britz's translation]

Poetically "shining white" is perhaps more ambiguous than "suiwerlik blank", and if one did not know the historical context, there would be little indication that it was actually referring to "Whites only". A Rachelbeeld or vision of 
Rachel is a direct reference to the long-suffering Rachel of the Old Testament and is particularly illuminating within the context of a burgeoning nationalism in that it becomes a metaphor for the Afrikaner woman - white, long-suffering, religious.

Van der Merwe generously quotes from President Steyn's address at the unveiling of the monument in a section entitled "The memorial's message to the volk of South Africa":

What was the strength of the weak women that could generate such heroines? ... Blessed is a volk that has such women; and a volk that has sprung forth from such women does not have to fear for its future ... May [the memorial] stand as an inspiration to the volk ... And if there is anyone from whom Volk and Vaderland demand great and heavy sacrifices, let this memorial teach him to what sacrifices true love of the Fatherland has led to.

(Van der Merwe, 1926:12-13, Britz's translation.)

Emily Hobhouse's opening ceremony address is also extensively quoted from by Van der Merwe:

Even so did Destiny, the mighty Sculptor, ... like clay in his hands take these simple women and children from their quiet homes, mould and chasten them through the successive stages of their suffering, till at length, purified and perfected to the Master-mind by the fierce fire of their trial, they passed from human sight to forever in the sacred memory of your land. Their spirit which we feel so near to us today warns ever: 'Beware lest you forget what caused that struggle in the past. We died without a murmur to bear our part in saving our country from those [the British] who loved her not but only desired her riches'.

(In Van Reenen, 1984:403, my emphasis)

For Hobhouse, however, while God is undeniably male, the fatherland of Steyn and other Afrikaner officials at the function embodies the female principle. The grammatical rule in Afrikaans (although its application is more relaxed these days) stipulates that anything which is not biologically female, must be designated as male - one reason why the issue of fatherland is prevalent. But the grammatical rule collapses when historians write about the motherland. In English, the use of motherland and fatherland are interchangeable, depending, it would appear, on circumstances. In times of war, and when jingoistic sentiments are strong, England, the traditional motherland, is spoken of as the fatherland as can be seen in much World War I poetry: Pro Patria Mori (to die for the fatherland) being a sentiment that is often echoed. In my opinion, Hobhouse, who identified strongly with the travails of the Boer women during and after the war, displays in her use of South Africa as the motherland, a sensitivity toward the Boer women. If she had used the word "fatherland", she would have, as an Englishwoman, implied that Britain was the motherland - a situation that would 
have been untenable to almost every Boer man and woman. From a political point of view she could also have been implying the right of the Boer people to those republics which were lost to the British during the war. The motherland is the start and origin of a people, she seems to be saying. The fatherland is what it becomes. Afrikaner nationalists, however, have consistently referred to South Africa as the fatherland, thereby imposing further the idea of the gendered mother/volksmoeder.

Although Hobhouse's full address is placed as an addendum in Britz's (19551961) translation, it can be seen as significant that the part of Hobhouse's speech quoted above is omitted in Van der Merwe's text. Van der Merwe (1926:17) elects to close this section in his own words: "The memorial calls with mighty voice for sacrifice to God and Fatherland". He also neglects to quote the following words in the closing paragraphs of Emily Hobhouse's address: "They [the Boer women] have shown the world that never again can it be said that woman deserves no right as Citizen because she takes no part in war. This statue stands as a denial of that assertion. Women in equal numbers to men earned the right ..."(Van Reenen, 1984:407, Hobhouse's italics).

The last two thirds of Van der Merwe's brochure is devoted to biographical sketches of President Steyn ( 5 pages), General de Wet ( 3 pages) and Emily Hobhouse (22 pages). The greater number of pages devoted to Hobhouse is used to give the reader background information regarding her travels around the camps in the Cape and Free State as well as her efforts to secure finances and support for the women and children.

Apart from the names mentioned in the biographical sketches, the names of the men involved in the erection of the memorial total 23 different male individuals. However, the names of Mrs Steyn and Miss Hobhouse appear regularly in the main section as well. The two women's stubborn endurance in the face of British imperial might is intended as role model by which Afrikaner women could mould themselves. But the role model provided is placed in terms of antiBritish, pro-Afrikaner sentiment; it is not placed with regard to the two women as individuals or as women in their own right.

\section{The weaning of the volksmoeders}

By contrast, Oberholster's 1961 publication lists the names of 51 different men who either served on the Monument Commission or were in some way involved in the opening ceremonies. Mrs Steyn's and Emily Hobhouse's names are barely mentioned and no quotes from the latter's address are given. Afrikaner nationalism had entered its second stage, and in a paradoxical twist, the breastfeeders of the nation are themselves suddenly weaned from the volk. The tone and writing style differ markedly from the first brochure published thirty years earlier. Oberholster's text is an almost sterile account of the erection and 
unveiling of the monument. It is filled with information such as the transportation of the sandstone blocks from Kroonstad and lists of working and subcommittee members. Once the reasons for the erection of the monument have been dispensed with in the first page and a half, the writer turns all his attention to the physical erection of the monument and the seemingly endless ceremonies of unveiling on 16 December 1913. In the 1961 document, little appeal is made to the volk and even less to the women. Apart from the fact that many of those people who had fought in the war or who had survived the concentration camps were dead by this time, it should also be remembered that the Afrikaner's political and economic circumstances had changed so significantly from the period after the Anglo-Boer War, that major, emotionally-laden appeals to become a volksmoeder or an integral part of the fledgling volk were hardly necessary. Consequently, the image of the Afrikaner woman nurturing the volk was jettisoned. The Women's Monument had become the symbol of unmitigated nationalist success. Albert Grundlingh (telephone conversation on 15 January 1994) makes the point that Oberholster, in the spirit of "scientific history" attempts to "depoliticise" the monument, by placing it above history, by sanitising its emotive content - hence the brick-by-brick account. Oberholster, who taught History at the University of the Orange Free State, placed himself in the modernist, scientific school of thought. While this may indeed be the case, it cannot be dismissed that Oberholster was simply also utterly enmeshed in the inescapability of the discourse he found himself in. Volksmoederskap, as the dismissal of this phenomenon in the 1961 brochure manifests itself, is not after all a "natural reality" but a product of a dispositif, a system of discourses and practices.

In literary circles also, the once revered notion of volksmoeder had become an object of denigration. In Apochrypha, M.M. Walters (1969:56) writes:

Volksmoeders van V.V.V.-vergaderings, onwrikbaar by die werk - kompeteer

by die pastorie(s)pens en basaar - vol, voller, volste hand op die heup - gemeentelike pilare -

[Volksmoeders of V.V.V meetings (women's organisations)/ undaunted at their place of work - compete / at parish(es) pantries, stomach and basaar - full, fuller, fullest / hand on the hip - pillars of society - ] (in Brink, 1986:188, her translation.)

The redundancy of the volksmoeder as mother is echoed by N.P. van Wyk Louw in Rondom eie werk (1970:18): “... maar toe ek ... sê, 'En hy kan dalk weer publiseer ...', was dit of ek van 'n deftige volksmoeder gesuggureer het dat sy dalk nog weer 'n werklike moeder kon word. Ek het gevoel asof ek onbedags iets obseens gesê het. [... when I ... said, 'And he could possibly publish again', it was as though I had intimated that a stately volksmoeder could possibly 
become a real mother once more. I felt as if I had said something unholy [sic: obscene] - in Brink, 1986:188, her translation]. So too, in Jeanne Goosen's much prescribed "Waterkloof 1974", the notion of volksmoeder is not only mocked but the poem also reflects an anti-nationalistic sentiment (1975:44).

Partially enclosing the National Women's Monument's obelisk and statuary is a low encircling wall. Oberholster, writing when most of the protagonists in his publication were already dead, had the following to say: "Upon completion of the Monument it was felt that it would only really be complete until a statesman, a warrior and a man of God lay buried there" (1961:21, my emphasis). We learn then that President M.T. Steyn, General C.J. de Wet and Dr. J.D. Kestell (a theologian) were buried within the embrace of the encircling arms of the surrounding wall. Emily Hobhouse's ashes were placed in a wall niche to one side and Mrs. Steyn was buried in her husband's grave (despite her wishes to the contrary).

The constructed images of the Afrikaner woman during the so-called pre-victory days of nationalism emphasised her role as servant to the volk, as nurturer, keeper of moral standards, as an educative influence and promoter of the language on behalf of the volk. Brink unequivocally calls such construction "man-made woman" (1990). Oberholster, however, consistently gives precedence to lists of male Commission members and official speakers at the opening ceremonies, foregrounding all the plans regarding the erection and unveiling of the monument and revealing through such discourse that the Afrikaner woman has been placed even further outside the modern historical process. Afrikaner nationalism was a success and women no longer needed to be mobilised.

\section{Rest in peace}

By the 1980s the Commission felt it was time to publish a new brochure which would "to a greater degree, radiate the spirit of the Monument" (Van Schoor 1993: Foreword by Col. F.J. Jacobs). M.C.E. van Schoor was commissioned to write the work which eventually appeared in Afrikaans in 1993. In his Foreword, Jacobs states that foreign interest in the Monument and War Museum was increasing and that this work would soon be available in English. To date the translation has not been forthcoming, and, in a sense, it is not surprising. The Prologue by Van Schoor is almost untranslatable, written in what can only be called a pastoral lyrical style which echoes the nostalgia of the 1930s plaasroman (farm novel) and which is devoted to "the spirit of the Monument". The first paragraph gives a fair indication of the stylistic nuances of these first few pages (Van Schoor, 1993:1):

Die sagte sonstrale van ' $n$ kwynende dag val op die monument. Dit is stil .. onpeilbaar stil. Die ligte roering van die karee- en olienhoutlower en die 
geroep van die tortelduifie na sy maat in die koppie digby verdiep die stilte. Hier het skeppingswerk en die natuur tot vrede en rus saamgesmelt. Hier swyg 'n mens, want in jou gees word dit stil om na ander stemme te luister.

[The soft rays of a declining day descend on the monument. It is quiet ... unfathomably quiet. The slight rustling of the karee and wild olive and the call of the little turtle-dove to its mate in the koppie nearby, enhance the quiet. Here, a work of creation and nature have coalesced into peace and rest. Here, a person falls silent, because within, your soul becomes still so that you can listen to other voices. (My translation.)]

The "other voices" raise questions in Van Schoor's mind: the first posed is whether this monument would only have found expression from a spirit as pure [opregte] as that of M.T. Steyn? The second question voices the possibility that the spirit of the monument can be found in the fact that the poorest of the poor contributed to its erection. The third possibility is that the obelisk symbolised not only the reawakening pride of a numerically decimated [getalsnietige] Afrikaner but also that of a reawakening nation. In 1913, ordinary Afrikaners were still struggling to put their lives and livelihoods together and very little could be said about Afrikaner nationalism. According to Hofmeyr (1991), people like Gustav Preller conjured up the idea of nationhood from events like the Great Trek to popularise the notion of a nation. But there is no doubt that the NWM came to be used as a metaphor for an emergent nation in the course of this century. Van Schoor merely mirrors discourses that emerged after the erection of the monument.

Like his predecessor, Oberholster, Van Schoor glosses over the war and the concentration camps (particularly surprising as a foreigner would no doubt like to know more) and concentrates instead on the "good stewardship" of the Commission. A list of Commission members since 1913 is given. All 57 of them are male. (Since the publication of the brochure, one female has been elected Kobie Gouws, a Freedom Front member of the Free State Legislature.)

The greater part of the 36-page brochure deals with how neat and tidy the Commission has left the area: extensive restoration to the crumbling sandstone blocks, a new drainage system, a redesign of the grounds coupled with a new environmental awareness. Descriptions and motivations for the erection of a series of statues of male burgers depicting stages of the war erected around the monument are given. Considering that Afrikaner nationalism had by now acquired subaltern status, the lyricism gives the impression that the women and events commemorated here are finally laid to rest, nestling in the vegetation, flirted by the coo of doves and the soft, basking light of a Free State dusk.

The third brochure, intended to elucidate and re-memory the National Women's Monument, has little to do with the women or the war - instead we are 
confronted by a Commission who wants it recorded that they have remained true to the spirit of the original statute.

In his discussion of the pastoral farm novels of C.M. Van den Heever of the 1930 s, Coetzee notes that the relationship between a good farmer and his land is a "proprietorship [which] comes to embody a marriage not so much between himself and the farm as between his lineage" (Coetzee, 1988:86). In like fashion the NWM Commission has such "proprietorship". The ancestral estate must be well stewarded not only for the ancestors but also for the descendants of the Afrikaner. The brochure has not become a commemorative document wherein the women and the war are remembered, but a text commemorating the all-inale Commission.

\section{Conclusion}

In this article I have used three texts which were intended to commemorate women in order to illustrate how one particular nationalism has manufactured, abandoned and then finally buried the women intended to bring it to fruition in the first place. In the history of Afrikaner nationalism, the category of woman has not remained stable. It has exhibited a fluidity influenced by male attitudes toward the nation and wherein women themselves have collaborated with and adapted to the complex and often contradictory relationships between nationalism and gender. Almost inevitably, issues of female identity have remained subsidiary to the nationalist imperative.

Believing that all nationalisms are part of the same constellation of discourses, it does not really matter whether a nationalism has subaltern status or whether it has achieved statehood. Once any form of struggle is over, once life settles down again, women's issues run the risk of becoming ghettoised within nationalism. Putting aside for the moment South Africa's new constitution where women's rights are entrenched, I feel that the real issue for women generally and feminism in particular, is to avoid a status of affiliation to calls for nationhood. Much like the women scouts and fighters of the Mau Mau in Kenya and female veterans of liberation struggles in states such as Zimbabwe and Namibia, South African women's involvement in the struggle will be largely forgotten and calls for national homogeneity will subsume issues of gender. One might argue that it is not nationalism per se which is the culprit, but patriarchy which "closes off" the woman. But until there is a nationalism which forces the patriarch to re-evaluate the relationship between nationalism and gender, I feel that the very configurations of a nationalist imperative demand complicity by women. Nationalism, says Kandiyoti, "[exerts] pressure on women to articulate their gender interests within the terms of reference set by nationalist discourse" (quoted in Graham, 1996:366). Gender then becomes subaltern to a nationalism promoted with a determinism to become the dominant discourse again. Within such a discourse, despite differences of class, economic status and race, gender 
is forced into an "affiliation" with nationalism to press its claims. Radhakrishnan (1992:78) also notes that

... the politics of nationalism become the binding and overarching umbrella that subsumes other and different temporalities ... [The] ideology of nationalist politics ... acts as the normative mode of the political as such ... consequently, the women's question is constrained to take on a nationalistic expression as a prerequisite for being considered 'political'.

African nationalism, while it was still an anti-colonial nationalism, had as its aim to become a State. Now that it is the State, the new nationalism will succeed "precisely because it imitates so exactly the State which preceded it" (Graham, 1996:369). Any imperative toward nationalism has to make use of the same homogenising rhetoric in order to succeed. Women will be expected to collaborate.

\section{Bibliography}

Brink, Elsabé. 1986. The Afrikaner Women of the Garment Workers' Union, 1918-1939. Johannesburg: Wits. (M.A. Dissertation.)

Brink, Elsabé 1990. Man-made women: gender, class and ideology of the volksmoeder. In Walker, C (ed) Women and gender in Southern Africa to 1945. Claremont : David Philip. p. 273-292.

Britz, D.P. s.a. (1955-1961). The National Women's Momument. Translation of Die Nasionale Vrouemonument by N.J. van der Merwe. Bloemfontein : Sentrale Pers.

Coetzee, J.M. 1988. White writing: on the culture of letters in South Africa. New Haven : Radix

Gaitskell, Deborah \& Unterhalter, Elaine. 1989. Mothers of the nation: a comparative analysis of nation, race and motherhood in Afrikaner nationalism and the African National Congress. In: Yuval-Davis, N. \& Anthias, F. (eds.) Women-Nation-State. Basingstoke Macmillan. p 58-78

Goosen, Jeanne. 1975. Orrelpunte. Johannesburg : Perskor.

Graham, Colin. 1996. Subalternity and gender: problems of post-colonial Irishness. Journal of Gender Studies, 5(3):363-374.

Hofmeyr, Isabel. 1991. Popularising history: the case of Gustav Preller. In: Hill, R., Muller, M \& Trump, M African studies forum, volume 1. Pretoria : Human Sciences Research Council. p. 49-76.

Kandiyoti, D. 1996. Identity and its discontents: women and the nation. In: Graham, Colin Subalternity and gender: problems of post-colonial Irishness. Joumal of Gender Studies, 5(3):363-374

Oberholster, J.J. 1961. Die Nasionale Vrouemonument (Bloemfontein). Bloemfontein : Die Nasionale Vrouemonument-kommissie.

Pakenham, Thomas 1982. The Boer War. London : Futura

Parker, A., Russo, D., Summer, D \& Yaeger, P. (eds.) 1992. Nationalism and sexualities. London : Routledge.

Postma, W. (Okulis, Dr.) 1918. Die boervrouw: moeder van haar volk. Bloemfontein : De Nationale Pers.

Radhakrishnan, R. 1992. Nationalism, gender and the narrative of identity. In: Parker, A. et al. Nationalism and sexualities. London : Routledge. p. 77-95. 
Stockenstrom, Eric 1921. Die vrou in die geskiedenis van die Hollands-Afrikaanse volk. Kaapstad : Pro Ecclesia.

Stockenstrom, Eric. 1944. Geskiedenis van die vrouebeweging en die vrouestemreg in SuidAfrika tot 1930. Stellenbosch : US. (D.Phil. thesis.)

Van der Merwe, N.J. 1926. Die Nasionale Vrouemonument. s.l. : s. n

Van Heyningen, E. 1991. Women and the second Anglo-Boer War. Paper delivered at the Conference on Women \& Gender in Southern Africa, Durban, 1991.

Van Reenen, Rykie. (ed.) 1984. Emily Hobhouse: Boer War letters. Cape Town \& Pretoria Human \& Rousseau

Van Rensburg, A.P. 1966. Moeders van ons volk. Johannesburg : Afrikaanse Pers-Boekhandel.

Van Schoor, MC.E. 1993. Die Nasionale Vrouemonument. Bloemfontein: Oorlogsmuseum van die Boererepublieke.

Van Wyk Louw, N.P. 1970. Rondom eie werk. Kaapstad : Tafelberg.

Walker, Cherryl. 1990. Women and gender in Southern Africa to 1945. Claremont : David Philip

Walters, M M 1969. Apochrypha. Kaapstad : Nasionale Boekhandel.

Yuval-Davis, Nira \& Anthias, Floya. (eds.) 1989. Mother - Nation - State. Basingstoke Macmillan. 